\title{
Tramas e tessituras na Economia Solidária: uma análise da influência das relações de pessoalidade na interinstitucionalidade da Economia Solidária
}

Brenno Gomes da Silva Mauro

Curso: Mestrado em Sociologia

Data de defesa: 27 de fevereiro de 2009

Orientadora: $\operatorname{Prof}^{\mathrm{a}} \mathrm{Dr}^{\mathrm{a}}$ Analia Laura Soria Batista

\section{Resumo}

A pesquisa discute a influência das relações de pessoalidade (amizade, confiança e reciprocidade) na construção das desigualdades 
ou assimetrias existentes nas relações interinstitucionais estabelecidas entre quatro cooperativas de catadores de materiais recicláveis (enquanto sujeitos da economia solidária) e instituições ou atores do setor público (Estado, governos, bancos públicos, etc.), do setor privado (empresas, indústrias, firmas, etc.) e da sociedade civil organizada, também conhecida como terceiro setor (Ongs, organizações internacionais, etc.) da região do Distrito Federal (Brasil). Procurou-se analisar as raízes históricas e as diversidades de concepções do conceito de economia solidária, orientadas por diferentes correntes teóricas, como as correntes marxista e maussiana. Abordou-se ainda a questão das pontualidades das políticas públicas para o setor, bem como a idéia da fragilidade socioeconômica da Economia Solidária: ambas relacionadas à questão da interinstitucionalidade.

$\mathrm{Na}$ abordagem empírica, utilizou-se a teoria das redes sociais como metodologia, assim como o método qualitativo e a pesquisa de campo para analisar o processo de construção das desigualdades verificadas nas relações interinstitucionais na Economia Solidária, de acordo com o recorte metodológico realizado.

Por meio da pesquisa de campo realizada, constatou-se que precariedade e informalidade ainda estão presentes na realidade das cooperativas de catadores estudadas. Em termos interinstitucionais, observou-se que aspectos como as diferentes flexibilidades existentes nas relações entre os atores envolvidos nessa trama (dinâmica socioeconômica) variavam em função da natureza das esferas sociais de onde tais atores provinham (setores público, privado e terceiro setor). Dessa forma, o grau de influência das relações de pessoalidade nas desigualdades ou assimetrias variou de acordo com a natureza das relações (políticas, econômicas ou filantrópicas) envolvendo as cooperativas estudadas.

Palavras-chave: economia solidária; cooperativas de catadores; relações interinstitucionais; redes sociais; pessoalidade. 